Zorana Z. Đukić*

Univerzitet u Beogradu

Filološki fakultet https://doi.org/10.18485/analiff.2020.32.2.7

821.135.1(497.11).09-14 Штефан Ф.

Originalni naučni rad

Primljen: 11.04.2020

Prihvaćen: 18.010.2020

\title{
POLOŽAJ ŽENA U MANJINSKOM RUMUNSKOM DRUŠTVU XX VEKA U SRBIJI: KROZ PRIZMU POEZIJE FLORIKE ŠTEFAN ${ }^{1}$
}

Književnost rumunske nacionalne manjine nastala u periodu nakon završetka Drugog svetskog rata predstavlja svojevrsnu refleksiju socijalno-istorijskih prilika u Srbiji. Poezija i proza pisana polovinom prošlog veka ukazuju na pojedina pitanja od krucijalnog značaja za ovu etničku zajednicu, a jedno od njih je svakako i pitanje statusa žena. U ovom radu upoznaćemo se sa delom jedne od najistaknutijih srpsko-rumunskih pesnikinja iz Vojvodine, Florikom Štefan (Florica Ștefan), i na primerima odabrane poezije saznati zbog čega njena lirika zauzima značajno mesto kako u manjinskoj, tako i u većinskoj, srpskoj književnosti. Specifičan diskurs, poetski pristup i stil otkriće nam ličnu empatiju pesnikinje prema sudbinama rumunskih žena, ali i eksplicitnukritiku patrijarhalnog društva. Zalaganja Florike Štefan za emancipaciju žena i unapređivanje njihovog položaja u društvu analiziraćemo ne samo kroz prizmu njene umetnosti, već i kroz druge aktivnosti koje ovu pesnikinju čine snažnim ženskim glasom rumunske nacionalne manjine čije je stvaralaštvo u znaku jasne tendencije da ukaže na neravnopravan, potčinjen i neprihvatljiv status žene u rumunskom manjinskom društvu XX veka.

Ključne reči: Florika Štefan, ženska poezija, rumunska manjinska književnost, feminizam

\section{Uvod: Književno-kulturološki kontekst}

Literarno stvaralaštvo autora pripadnika nacionalnih manjina usko je povezano sa socijalnim i političkim prilikama u Srbiji sredinom XX veka. Shodno tome, književna kritika, analiza dela, individualnih i kolektivnih dostignuća u oblasti kulture i umetnosti, neizostavno podrazumeva

\section{* zorana.djukic92@gmail.com}

1 Ovaj rad je nastao u okviru projekta br. 178029 Ministarstva za prosvetu, nauku i tehnološki razvoj Republike Srbije, Knjiženstvo, teorija i istorija ženske književnosti na srpskom jeziku do 1915. godine. 
sagledavanje šire slike, te shvatanje specifičnih uslova u kojima su se rađale manjinske književnosti. U takvim okolnostima, istupanje iz društvenih okvira manjinske zajednice i suprotstavljanje potencijalnoj hegemoniji tumači se kao posebno hrabar potez. Shodno tome, socijalno angažovana poezija, a najviše poezija protkana snažnim ženskim glasovima, feminističkim idejama i otporu prema inferiornom položaju žena, kakva je poezija srpsko-rumunske pesnikinje Florike Štefan (Florica Ștefan), neodvojiva je od socijalno-kulturološkog konteksta.

Počeci rumunske književnosti u Vojvodini korespondiraju sa stvaranjem rumunske nacionalne manjine $u$ našoj zemlji. $U$ periodu nakon završetka Drugog svetskog rata rumunska manjinska zajednica otpočinje svoju borbu za očuvanje kulturnog i društvenog identiteta. Dolazi do institualizacije kulturnih društava i unija čiji su inicijatori bili istaknuti i obrazovani predstavnici manjine. Nekolicina književnika, filologa i drugih umetnika u novonastalim prilikama svojim zalaganjem postavlja temelje rumunske kulturne baštine i mapira je na društveno-umetničkoj sceni Srbije.

Tada aktuelni socijalistički režim pruža izuzetno povoljne uslove za razvoj manjinskih, tačnije književnosti na drugim jezicima. Podsticanjem kulturološkog diverziteta u SFRJ jačao se kolektivni duh manjinskih naroda kojima je za kratko vreme pružena prilika da van matice osnuju svoje društvene zajednice i obezbede osnovna ljudska prava na jezik, obrazovanje, kulturu i tradiciju. Novi koncept „bratstva i jedinstva“ imao je za cilj postizanje jednakosti na socio-kulturološkom planu, što je sasvim očekivano rezultiralo ujedinjenjem rumunskog naroda u tendenciji da svoje tradicionalne kanone prenese i u novu društvenu zajednicu (Flora, 1981:9-27).

Pedesetih godina prošlog veka zvanični jezik Socijalističke Federativne Republike Jugoslavije bio je srpskohrvatski. Bio je to službeni administrativni jezik, korišćen još u slučajevima vojnog komandovanja i obuke. Ustavom Republike definisani su jezici, dijalekti i pisma koja su se nalazila u široj upotrebi. Iako je posmatrano sa šireg aspekta rumunski jezik bio manjinski, on je na teritoriji Vojvodine na kojoj je bilo naseljeno rumunsko stanovništvo bio jedan od većih jezika. Takav položaj Rumunima je omogućio da svoju kulturu predstave kao jednu od razvijenijih manjinskih kultura u Srbiji. Državno „konkretizovanje realizacije na prava manjina" (Flora, 1981:14) dovelo je do konačne institualizacije rumunske kulture u vidu osnivanja kulturnih i književnih unija, časopisa, redakcija, televizijskog i radijskog programa na rumunskom jeziku. 
Dakle, zahvaljujući određenom broju istaknutih pojedinaca, rumunsko kulturno nasleđe zaživelo je i van matične države, u okruženju u kome nije bilo nimalo lako sačuvati sopstveni identitet. Među njima nalaze se imena poput najpoznatijeg rumunskog lingviste, književnika i erudite iz Vojvodine, Radua Flore, zatim esejiste Slavka Almažana (Slavco Almăjan) čiji radovi i danas svedoče o teškim vremenima i začecima rumunske književnosti na teritoriji naše zemlje, Vaska Pope, rumunsko-srpskog pesnika koji predstavlja značajnu sponu između kulture ova dva naroda, pisca Jona Balana (Ion Bălan) i drugih umetnika među kojima se nalazi i jedna žena pesnikinja Florika Štefan. U nastavku rada poseban osvrt pravimo na njena zalaganja po pitanju učvršćivanja srpsko-rumunskih književno-kulturoloških odnosa i kroz prizmu njene pisane reči pokušavamo da ustanovimo $\mathrm{u}$ kakvom je položaju tada bilo ne samo rumunsko manjinsko stanovništvo, već i rumunska žena.

\section{Florika Štefan: Ženski glas rumunske nacionalne manjine}

Ono što se izdvaja kao posebna karakteristika rumunskog akademskog društva u Srbiji pedesetih godina prošlog veka je iznenađujuće odsustvo stereotipizacije i diskriminacije prema ženskom polu, budući da je situacija u nižim društvenim krugovima bila sasvim drugačija. U želji da postave stubove rumunske kulture u stranom okruženju jednako su bili ujedinjeni i muškarci i žene. Ovakav stav rumunske zajednice prokrčio je put pesnikinjama i književnicama od kojih su pojedine postale simboli ne samo rumunske, već i srpske poetike.

Kada je reč o istaknutim intelektualcima i autorima koji su pripadali rumunskoj nacionalnoj manjini, posebno izdvajamo ime Florike Štefan. U tradicionalnoj, patrijarhalnoj sredini kakva je Vojvodina, bilo je neophodno čuti snažan ženski glas. Period o kome govorimo u Srbiji je generalno bio produktivniji za muškarce, a samim tim i u manjinskim zajednicama poput rumunske, koja je osim stvaranja umetnosti zarad umetnosti imala zadatak da ni iz čega stvori književnost na ovom manjinskom jeziku. Od samih početaka, odnosno od vremena nastanka rumunske unije 1945. godine, književnost ovog naroda imala je i žensku perspektivu.

Za uključivanje mladih i talentovanih književnica u kulturne tokove zajednice zaslužan je Vasko Popa. Vasko Popa ujedno je i jedan od najznamenitijih pesnika koji „,markira početak jedne nove, modernistički akcentovane etape u razvoju srpske lirike pedesetih godina“ (Cidilko 2008:17). 
Godine 1946, Popa je prisustvovao i osnivanju književnog časopisa Libertatea literară (Književna sloboda), a kasnije i časopisa Lumina (Svetlost), koji su obeležili početak stvaralaštva Florike Štefan. Već početkom 1947. postaje glavni i odgovorni urednik ovog časopisa orijentisanog ka rumunskoj književnoj kritici i ujedno prvog rumunskog književnog časopisa u tadašnjoj Jugoslaviji. U redakciji su bili Radu Flora, profesor Filološkog fakulteta u Beogradu, Aurel Gavrilov i Jon Markovićan (Ion Marcovicean) (Popović, 2009:9-20). Književni časopisi u čijem osnivanju i uređivanju je učestvovao Popa bili su u tom trenutku jedini svetionici rumunske književnosti. Iz tog razloga, pesnik se zalagao za promociju i afirmisanje mladih talenata, samim tim stimulišući kulturni i umetnički duh među rumunskim življem.

Pod njegovim mentorstvom počinju da pišu i aktivno objavljuju svoje radove i žene, čime rumunska manjinska književnost dobija potpuno novu dimenziju i doživljaj. Tradicionalne ženske teme, poput ljubavi, čežnje i patnje postaju deo rumunskog lirskog kolaža. Međutim, dela mladih književnica jednako doprinose i građenju slike o društveno-kulturološkim prilikama tog vremena, budući da se u njihovim delima tretiraju važna socijalna pitanja. Tako osim ljubavnih motiva njihovo stvaralaštvo obeležava i rodoljubiva, socijalna poezija koja reflektuje stanje i međuljudske odnose unutar patrijarhalne manjinske zajednice na polovini XX veka. Pored toga, mlade autorke podsticane su na stvaranje književnosti na bilingvalnom nivou, te je ženska književnost u Vojvodini jednako nicala i na srpskom i na rumunskom jeziku.

Ohrabrena novim kulturnim talasom, Florika Štefan, jedna od kasnije će se ispostaviti najistaknutijih rumunskih autorki u pokrajini, počinje svoj književni put publikujući svoje radove u poznatim književnim časopisima tog vremena. Ova rumunska pesnikinja rođena je 1930. godine u Lokvama, malom mestu u Banatu. Nakon svršene gimnazije, dalje obrazovanje nastavlja na Filozofskom fakultetu u Beogradu. Već sa 15 godina počinje da piše pesme i postaje aktivan član rumunskih književnih društava između 1945. i 1946. godine. Kao višestruko objavljivana mlada pesnikinja, Florika Štefan postaje i član uredništva najrenomiranijih književnih časopisa kao što je Lumina (1948-1954), gde zajedno sa Popom i drugim rumunskim intelektualcima postavlja temelje moderne rumunske proze i poezije u Vojvodini.

Međutim, njeno uredničko iskustvo ne završava se u Lumini. Nekoliko godina kasnije, kao već formirana i priznata pesnikinja, Florika 
Štefan učestvuje u osnivanju časopisaFemeia nouă, prvog časopisa na rumunskom jeziku posvećenog ženskoj čitalačkoj publici u Srbiji.Časopis je publikovan u periodu od 1950. do 1953. godine, sa ciljem da ,doprinese kulturnom uzdizanju rumunskih žena, posebno onih koje pripadaju ruralnim sredinama" (Stojaković, 2013:38). Na taj način ova pesnikinja relativno rano, na samom početku svog umetničkog puta, otkriva feminističke tendencije i postaje ,ženski glas” rumunske nacionalne manjine. Kroz svoje stihove Florika Štefan dočarava živote vojvođanskih Rumunki, dajući istovremeno i pregled svih dešavanja unutar zatvorenog kruga rumunske zajednice.

S obzirom na to da je rođena u rumunskoj porodici, Florika Štefan počinje da piše prvenstveno na rumunskom jeziku, a prvu zbirku poezije na srpskom jeziku objavljuje 1956. godine. Tada se okreće pisanju na većinskom, srpskom jeziku, čime stiče širu čitalačku publiku i, videćemo kasnije, dobija status značajne srpske pesnikinje. Pesme ove autorkeuvrštene su u nekoliko poznatih antologija srpske ženske lirike, među kojima se nalaze i pesme najvećih domaćih pesnikinja poput Desanke Maksimović, Mire Alečković, Milice Stojadinović Srpkinje i drugih ${ }^{3}$. Samo dve njene zbirke objavljene su na maternjem jeziku: Cântecul tinereții (Pesme mladosti, 1949.) i Lacrimi şi raze (Suze i zraci, 1953.), iako su mnogi od njenih stihova pisanih na srpskom kasnije prevedeni na rumunski i objavljeni u Rumuniji. Uspeh koji je postigla ogleda se u činjenici da je ,njeno prisustvo živo kako sa konačnih aspekata dela na srpskohrvatskom jeziku, tako i u književnom pokretu izrazana rumunskom jeziku, jer pesnikinja nikad nije zanemarivala svoje poreklo, ni ono rumunsko, ni ono seljačko" (Flora, 1976:78), što možemo primetiti i u pesmama odabranim za ovu analizu.

Kada je reč o definiciji pesničkog izraza Florike Štefan, kao najdominantnije izdvajaju se ljubavne i društveno značajne teme, usled čega je književni kritičari doživljavaju kao pesnikinju čija je poezija konfesionalna, subjektivna i fokusirana na istorijsku i socijalnu percepciju sveta (Deaconescu, 1989:9). Personalni stavovi pesnikinje duboko su ukorenjeni u njeno stvaralaštvo, a „etika i poetika njenog mišljenja i pevanja istovetna

2 Reč je o zbirkamaNajlepše ljubavne pesme srpskih pesnikinja, priredila Gordana Simeunović (2013),Srpske pesnikinje od Jefimije do danas, priredili Stevan Radovanović i Slobodan Radaković (1972), Svetiljke na putu: Antologija posleratne srpske poezije, priredio Milivoje Marković (1986), Zaljubljeni Orfej: antologija srpske ljubavne poezije, u izdanju Saveza Srba u Rumuniji (2006). 
je s prostorom i vremenom“ (Šindić, 2001:165). Među mnoštvom ljubavnih pesama koje pretežno čine umetnički opus Florike Štefan, nailazimo i na poeziju prožetu dubljim emocijama, poeziju koja dotiče uvek aktualne teme o stereotipizaciji, uniformnosti i ograničenosti razmišljanja, kroz čije stihove se probija vapaj za promenom. Književni kritičar Jon Karajon (Ion Caraion) dodaje i da Florika Štefan piše „kamenitu poeziju u kojoj su oštrina i nemir prirodne posledice brutalnog života" (prema Popović, 2013:337).Upravo ove karakteristike izdvajaju Floriku Štefan kao uticajnu književnicu, intelektualku i pre svega aktivistkinju za ženska prava. Njena posvećenost shvatanju ženskog senzibiliteta i sudbine u posleratnom, manjinskom, ruralnom vojvođanskom društvu rađa društveno angažovanu poeziju koja čitaocu otvara novu perspektivu. U odabranim pesmama koje ćemo predstaviti u nastavku uočićemo dve posebne vrste pesničke empatije - prema devojkama (mladim ženama) i prema majkama. Sa istom emocijom portretisani su likovi žena u različitim životnim dobima, različitih statusa, ali jednako teškim sudbinama. Ne izostaje ni karakterizacija maskuliniteta, budući da se njegova dominacija navodi kao glavni uzrok ženske patnje.

Prvi simboličan prikaz života rumunske seljanke pronalazimo u pesmi Devojke i žene mog porekla iz ciklusa Glasovi i sudbine. Ova pesma već svojim nazivom ukazuje na priču o ženamaiz vojvođanskih sela na polovini XX veka:

Sve vas znam devojke i žene mog porekla po pačjem hodu kao staru česmu iza prvog ugla ulice jer još uvek mirišete na velike sobe na brdo jastuka gde niste prespavale nijednu noć od bosiljka

Sve vas znam devojke i žene jer u istom ritmu okrećete svoje nedelje oko crkve i kržljavih mladića kao jato vrana što okreće svoju glad oko crkvenog tornja

Sve vas znam devojke i žene i jao, prodaju vaših šesnaest godina kao stoku na svim banatskim vašarima 
Uz rakiju i njive putuju vaša mladost i starost

s jednog kraja sela do drugog

Sve vas znam devojke i žene

kada rađate decu cvetaju njive

a kada vam se razboli život

od rađanja, kiša i sunca

pačjim hodom vraćate se ocu

da kletvom lečite sudbinu.

(1966:9)

Stihovi pesme surovo opisuju živote mladih žena čija je jedina svrha udaja, iliti „prodaja“, kako to pesnikinja slikovito naglašava. Rođene da budu žene, majke, sluškinje, mlade Rumunke nemaju nikakvu perspektivu u životu. One svoju mladost, ili bolje rečeno detinjstvo, provode oblećući oko „kržljavih mladića“" u nadi da će ih jedan od njih uzeti za suprugu. Dok rađaju naslednike, brinu o domu, porodici i marljivo rade u polju njihovu marljivost niko ne primećuje i ne priznaje, jer upravo to se smatra ženinom „dužnošću“. A kada više ne mogu da ispunjavaju tu svoju „dužnost“", kada ostare i razbole se, tada se seljanke ponizno vraćaju roditeljskom domu i ocu, muškarcu koji isto kao i njihovi muževi, ne shvata nesreću na koju su osuđene.

U jednoj od svojih najranijih pesama pod nazivom Tako sam se rodila, objavljenoj u istoimenoj zbirci (1956), Florika Štefan već ukazuje na inferioran položaj žene u tradicionalnom okruženju. Ovakratka pesma, koja tematski podseća naPriče o ženi, zbirku sefardske književnice Fride Filipović iz 1937. godine sačinjenu od 19 priča u kojima se predstavljaju životi žena sa različitim sudbinama (Hawkesworth, 2000:222), opisuje muke žene koja se nalazi pred porođajem i u iščekivanju tog događaja moli Svetog Arhanđela da joj podari naslednika. Ipak, upečatljiviji od majčinskog očaja i strepnje su likovi muškaraca, oca i dede koji okreću glavu od tek rođene devojčice, čime se već od samog dolaska na svet određuje život ženskog deteta:

Na zidovima od naboja znoj njenih porođajnih muka

- Sveti Arhangelu na konju dotakni tvojim krilima moj bol 
nek se muško rodi.

Svu noć je cvrčak pevao

u majčinom trbuhu.

Svu noć su je uragani ljuljali

nad žitnim poljima.

- Sveti Arhangelu na konju

daj da s prvim petlom

moj prvenac zaplače.

$\mathrm{Na}$ zidovima od naboja

samo prvi glas ženskog plača

- Sveti Arhangelu na konju

otac je okrenuo glavu, deda je okrenuo glavu, baba je prvim pelenama ubrisala suze...

(1956:33)

Navedeni stihovi ukazuju na jasnu progresiju ženskog saosećanja i razumevanja koje pesnikinja pokazuje kako prema neudatim, mladim devojkama, tako i prema onima koje su već ispunile svoj bračnu dužnost i nalaze se pod snažnim pritiskom patrijarhata da rode muško dete. U suprotnom, nameće se stav da one neće ispuniti svoj ,zadatak“ i time otežati sopstvenu budućnost.

Sličnu deskripciju majčinske uloge pronalazimo i u pesmi Dnevna zapovest, publikovanoj u srpskoj književnoj reviji Vetrenjača 1956. godine. I ova, kao i prethodna pesma, samim naslovom aludira na nejednakost društvenog poretka u rumunskom selu. Kroz svoje stihove pesnikinja na vrlo simplifikovan način, kolokvijalnim jezikom, koncizno i eksplicitno čitaocima dočarava jedan sasvim običan dan u životurumunske seljanke, njenu žrtvu, marljivost, borbu sa prekim i nadmenim muškimkarakterom, ali i strepnju za život i sudbinu vlastite dece. Međutim, za razliku od prethodne, u ovoj pesmi otkrivamo da su identičan tretman imale i žene koje su rađale mušku decu, što samo potvrđuje pretpostavku da se reproduktivna sposobnost žena, kao i sam pol deteta, zapravo koristila (a neretko se koristi i danas), kao pretekst za širenje mizoginije. Po prvi put uočavamo i aluzije na psihičko i potencijalno fizičko nasilje nad ženama podstaknuto porocima koji su se tolerisali muškarcima i predstavljali kao sastavni deo njihovog karaktera: 
Ustajanje u dva: poori njivu kod Grede

Ustajanje u dva: posej njivu kod Ilandže

Ustajanje u dva: požnji žito kod Jarka

Ustajanje u dva: nosi đubre kod Begeja

Evo ti kutije duvana

sto dinara za svaki slučaj

(u sebi: doći će sigurno pijan)

nazobi konje

i melji žito u prvom susednom selu

Ja kuću držim na svojim leđima

kaže otac sinu

kad umrem bićeš gazda

(Testament još nije ostavio

jer tek ima sedamdeset godina

i još zna da zapoveda

pobogu, rođenom sinu...)

(1956:10)

Pesma Majčin dom, objavljena u zbirci Tako sam se rodila, ispunjena je posebnom emocijom ćerke koja pati zbog teške majčine sudbine. U jednoj slici predočen je isprazan i usamljenički životni vek obične seoske žene, majke i domaćice, za koju pesnikinja surovo kaže da su joj oči „,nepotrebne":

\author{
U prvoj krčmi na uglu \\ muž ti je prolumpovao seljačku mladost \\ od prve do poslednje čaše \\ ispio je sve do dna: \\ zoru, sunce i zvezdanu noć. \\ Ti si ostala bez očiju \\ u tvom krugu one su nepotrebne. \\ Od staje do ambara, \\ od zadimljene sobe do trule kapije \\ pas ti je jedini pratilac. \\ I tebi su oči nepotrebne.
}

(1956:37) 
Zahvalnost prema majčinskoj žrtvi, uprkos nezavidnom položaju u kome se nalazi, iskazana je u pesmi Majka, koja pripada istoj zbirci. Pesnikinja još jednom naglašava težinu bračnog života rumunske seljanke za koju još tvrdi i da je „sva od suza sazdana i očevih poniženja“ (1956:38).

Dakle, specifičan, odnosno empatičan pesnički izrazFlorike Štefan razlikuje njeno stvaralaštvo od ostalih rumunskih pisaca i pesnika ovog doba. U pesmama koje smo odabrali za analizu zapažamo izraženo saosećanje, žal i bol za izgubljenim, promašenim i praznim životima rumunskih seljanki koje su njihove protagonistkinje. Ovakvi motivi iziskuju poseban pristup. Pesnikinja je svesna ozbiljnosti poruke koju prenosi svojim čitaocima i iz tog razloga se opredeljuje za veoma jednostavan, lak, upečatljiv stil pisanja, poeziju koju karakteriše odsustvo rime, poeziju koja prati tok misli, ne ulepšava stvarnost, štaviše, prikazuje je na surov i sirov način, bez eufemističnih izraza i sa snažnom željom da u potpunosti prenese svoju emociju. Portreti rumunskih seljanki iz pesama Florike Štefan značajni su i po tome što ne govore samo o statusu Rumunki kao pripadnica nacionalne manjine. Naprotiv, oni su veoma slični prikazima srpskih žena i devojaka, te $u$ tom pogledu nećemo primetiti značajnu razliku između ženskog pitanja u manjinskoj i većinskoj sredini. Tokom XIX i XX veka društveni položaj žene u Srbiji bio je daleko od prihvatljivog. Identičnu sudbinu delile su i srpske, i rumunske seljanke suočavajući se sa jednako tradicionalnim vrednostima. Rad i konstantna briga o porodici i domaćinstvu ostavljali su vidljive posledice na fizički izgled ovih žena, što je predstavljeno i pojedinim delima naše književnosti. Stoga, tretirajući ulogu žene u muškom svetu, rumunska pesnikinja povlači paralelu između dva naizgled različita društva, ukazujući pritom na njihove centralne probleme.

Uz snažan revolt i očaj zbog potlačenog i neravnopravnog položaja žena, Florika Štefan kroz svoje stvaralaštvo takođe prezentuje lično viđenje ,idealnog“ odnosa između savremenog muškarca i savremene žene. Kratka priča pod nazivom Logorska vatra (Focuri de tabară) objavljena 1950. godine u časopisu Lumina otkriva autorkine vizije o muško-ženskom odnosu XX veka koje po svojoj suštini pripadaju izvornoj feminističkoj ideologiji i lako mogu biti primenljive i u današnje vreme. Naime, opisujući vreme radnih akcija u SFRJ, Florika Štefan naglašava sve jači poriv za promenom, odnosno kompletnom ravnopravnošću među polovima. U periodu bratstva i jedinstva koje je propagiralo jednakost u svakom smislu te reči, pesnikinja pronalazimogućnost da predstavi vlastiti koncept 
iste - ženu kao ravnopravnog učesnika radne akcije, sposobnu da obavlja iste poslove kao i muškarac i jednako se dobro snalazi i u kuhinji, i na gradilištu. Drugim rečima, muškarac i žena imaju identična prava na rad, hranu i zasluge. Ipak, tako snažna i sposobna žena ne zaboravlja nijednog trenutka svoju nežniju stranu, što se u delu ističe kratkim opisom cveta u kosi. Idealna žena socijalizma je slobodna, ravnopravna, vesela, raspevana, optimistična, provodi vreme sa prijateljima i aktivno doprinosi izgradnji novog, modernog društva (Ćorković, 2014:24). Ovakva vizija savršeno se uklapa u kulturno-istorijski kontekst vremena u kome je stvarala Florika Štefan i predstavlja željno očekivanu promenu u pogledu društvenog statusa žena. Međutim, utopijska ideologija o savršenom društvu bez razlika bila je samo privid, slika koja je srušena vrlo brzo nakon pada socijalističkog režima.

Osim temperamentnim suprotstavljanjima, prkosom i tragičnošću, sa kojima smo se već susreli, poezija Florike Štefan obiluje i prikazima istinskih, dubokih i tananih emocija. Njeni opisi devojačkih ljubavi neretko lebde između romantike i patetike, nosigurno ostavljaju snažan utisak. Pomenute karakteristike ne definišu literarno stvaralaštvo pesnikinje kao klasičan odraz feminizma, ali tretiranje pitanja roda, nacionalne pripadnosti i socijalno-istorijskog okvira zasigurno kreiraju posebnu formu feminističkog umetničkog izraza. Univerzalnost iskustava koja dominira u svakoj od analiziranih pesama približava pesničku poruku čitaocima, naglašavajući na taj način žensko pitanje kao jedno od glavnih društvenih problema. Ipak, jačinu feminističke ideje u poeziji Florike Štefan najbolje ćemo razumeti ukoliko je analiziramo zajedno sa njenim doprinosom u napretku svih pripadnica rumunske nacionalne manjine. Zalaganja za emancipaciju rumunskih žena, kao i podsticaj neafirmisanih autorki na književni rad, neizostavan su deo feminističke predstave o liku i delu ove pesnikinje. Na temelju njenih dostignuća stičemo utisak da je i pored svih poteškoća nametnutih od strane patrijarhalnog manjinskog društva ipak moguće izboriti se za svoj, ženski glas. U tom smislu, umetnost Florike Štefan izlazi is okvira klasičnog lirskog prikaza ženske sudbine.

\section{Zaključak}

Izuzetno subjektivna, konkretna i empatična poezija srpsko-rumunske pesnikinje Florike Štefan realističan je prikaz društvenih karakteristika XX veka koje su u znaku maskuliniteta. Položaj, uloga i sudbina žene u 
ratnom i posleratnom periodu predstavljaju teme od važnog značaja i tumačese sa više naučnih aspekata - istorijskog,sociološkog,kulturološkog. Kako bismo ih u potpunosti sagledali, važno je da obratimo pažnju i na žensku perspektivu koju nam pruža Florika Štefan. Nekolicina književnica, pesnikinja i feministkinja decenijama unazad pokušavala je da kroz svoj rad predstavi problem ženske inferiornosti i „,nevidljivosti“. Ako su se u nezavidnom položaju nalazile žene koje su pripadale nacionalno dominantnijoj zajednici, jasno se zaključuje da su pripadnice onih manjinskih imale dvostruko manje mogućnosti i prava. Etnički mozaik naše zemlje generisao je granice i razlike na socijalnom planu, kreirajući svojevrsnu predstavu o mikro i makro društvima. No, po pitanju sprovođenja patrijarhalnih normi, sve nacionalne grupe suočavale su se sa identičnim sistemom vrednosti.

Najrelevantnije izvore o navikama, životu, problemima i tradicijijednog manjinskog stanovništva pružaju nam njihovi istaknuti predstavnici, čuvari kulture i tradicije. Kada je u pitanju rumunska nacionalna manjina, među brojnim muškarcima koji su u prvoj polovini XX veka preuzeli na sebe zadatak izgradnje vlastite kulture i nacionalnog identiteta, izdvojila se Florika Štefan, intelektualka zahvaljujući kojoj se rumunska manjinska, ali i srpska književnost danas odlikuju snažnom lirikom i još snažnijom ženskom perspektivom. Važno je napomenuti da preko trideset naslova objavljenih na srpskom jeziku, među kojima su najpoznatije zbirke Tako sam se rodila, Zatvorene u svet, Dozvolite suncu, Treća žena, Mesto za ljubav, Koreni pesme, Luda ptica ljubavi, Put do sunca i dr, čine značajan doprinos srpskoj ženskoj poeziji.Ova autorka je zahvaljujući svojim publicističkim i prevodilačkim zaslugama postala važan ambasador srpske i rumunske kulture u dijaspori.Dobitnica je Oktobarske nagrade grada Novog Sada, nagrade „Jovan Popović”, „Milica Stojadinović Srpkinja”, kao i nagrade Društva književnika Vojvodine za životno delo i nacionalne penzije zbog izuzetnog doprinosa srpskoj kulturi.

Pesme odabrane za analizu u ovom radu samo su jedan deo od mnoštva prikaza ženskih sudbina ove pesnikinje, koje se, uzevši u obzir istorijske, socijalne i političke prilike, mogu okarakterisati kao univerzalne na našim prostorima. Time stvaralački opus Florike Štefan ostavlja dubok trag u domaćoj književnosti i kulturi, svedoči o teškim, surovim vremenima tokom kojih je unutar rumunske i srpske zajednice i pored svih konvencionalnih normi ipak jačao feministički duh i želja za promenom. 


\section{LITERATURA}

Cidiliko, V. (2008). Studije o poetici Vaska Pope. Beograd: Službeni glasnik.

Ćorković, M. (2014). Kultura sećanja u proznoj manjinskoj rumunskoj književnosti(doktorska disertacija).Filološki fakultet: Beograd.

Deaconescu, I. (1989). Poezie şi epocă. Novi Sad: Libertatea.

Flora, R. (1976). Rumunska književnost u Vojvodini. Novi Sad: Matica Srpska.

Flora, R. (1981). Zapisi: Književnost i kultura Rumuna u SAP Vojvodini. Zrenjanin: Biblioteka Žarko Zrenjanin.

Hawkesworth, C. (2000). Voices in the Shadows: Women and Verbal Art in Serbia and Bosnia. Budapest: Central European University Press.

Popović, R. (2009). Vasko Popa mit i magija. Beograd: Službeni glasnik.

Popović, V. (2013 ). Voci feminine în diasporă - poezia de limba română din Voivodina.In L. Botoșineanu, O. Ichim, C. Maticiuc, E. Tamba (ed), Metafore ale devenirii din perspectiva migrației contemporane. Național și internațional în limba și cultura română (pp. 335-343). Iași: Institutul de Filologie Română „A. Philippide” al Academiei Române.

Stojaković, G. (2013). Rodna perspektiva u novinama Antifašističkog fronta žena (1945-1953). Novi Sad: Zavod za ravnopravnost polova.

Šindić, M. (2001). Kritika poezije - eseji i studije. Novi Sad: Zmaj.

Štefan, F. (1956). Dnevna zapovest. Vetrenjača, br. 7, str. 10.

Štefan, F. (1956). Takva sam se rodila. Vrbas: Progres.

Štefan, F. (1966). Glasovi i sudbine. Novi Sad: Progres. 


\title{
Zorana Đukić
}

\section{THE POSITION OF WOMEN IN THE MINORITY ROMANIAN SOCIETY OF THE 20TH CENTURY IN SERBIA: THROUGH THE PRISM OF FLORIKA ŠTEFAN'S POETRY}

\begin{abstract}
Summary
The Romanian minority literature created in period after Second World War, represents a kind of reflection of the socio-historical circumstances in Serbia. Poetry and prose written in the middle of the last century point to certain issues of crucial importance for this ethnic community. One of them is certainly the issue of the position of women. In this paper we will get familiar with the work of one of the most prominent Serbian-Romanian female poets from Vojvodina, Florika Štefan (Florica Ștefan), and learn from examples of selected poetry why her lyrics occupy an important place in Romanian minority literature and Serbian literature, as well. The specific discourse, poetic approach and style will reveal the poet's personal empathy towards destinies of Romanian women along with an explicit critique of patriarchal society. We will analyze Florika Štefan's advocacy for the emancipation of women and the advancement of their position in society not only through the prism of her art, but also through other activities that make this poet a strong female voice whose work has clearly marked the status of women in Romanian minority society of the 20 th century.
\end{abstract} feminism

Keywords: Florika Štefan, women's poetry, Romanian minority literature, 